\begin{tabular}{l|l}
\hline $\begin{array}{l}\text { 2. To: (Receiving organization) } \\
\text { Distribution }\end{array}$ & $\begin{array}{l}\text { 3. From: (Originating Organization) } \\
\text { WRAP Engineering }\end{array}$ \\
\hline 5. Proj./Prog./Dept./Div.: & $\begin{array}{l}\text { 6. Design Authority/ Design Agent/Cog. } \\
\text { Engr.: } \\
\text { W-026/WRAP/WMH }\end{array}$
\end{tabular}

8. Originator Remarks:

This EDT is to release the Technical Safety Requirements (TSR) for the WRAP Facility as Supporting documentation.

11. Receiver Remarks: 11A. Désign Baseline Document? [X] Yes [] No
4. Related EDT No.:
N/A

7. Purchase Order No.:

$\mathrm{N} / \mathrm{A}$

9. Equip./Component Ho.:

N/A

10. System/Bldg./Facility: 2336-W

12. Major Assm. DHg. No.: N/A

13. Permit/Permit Application No.: N/A

14. Required Response Date: N/A

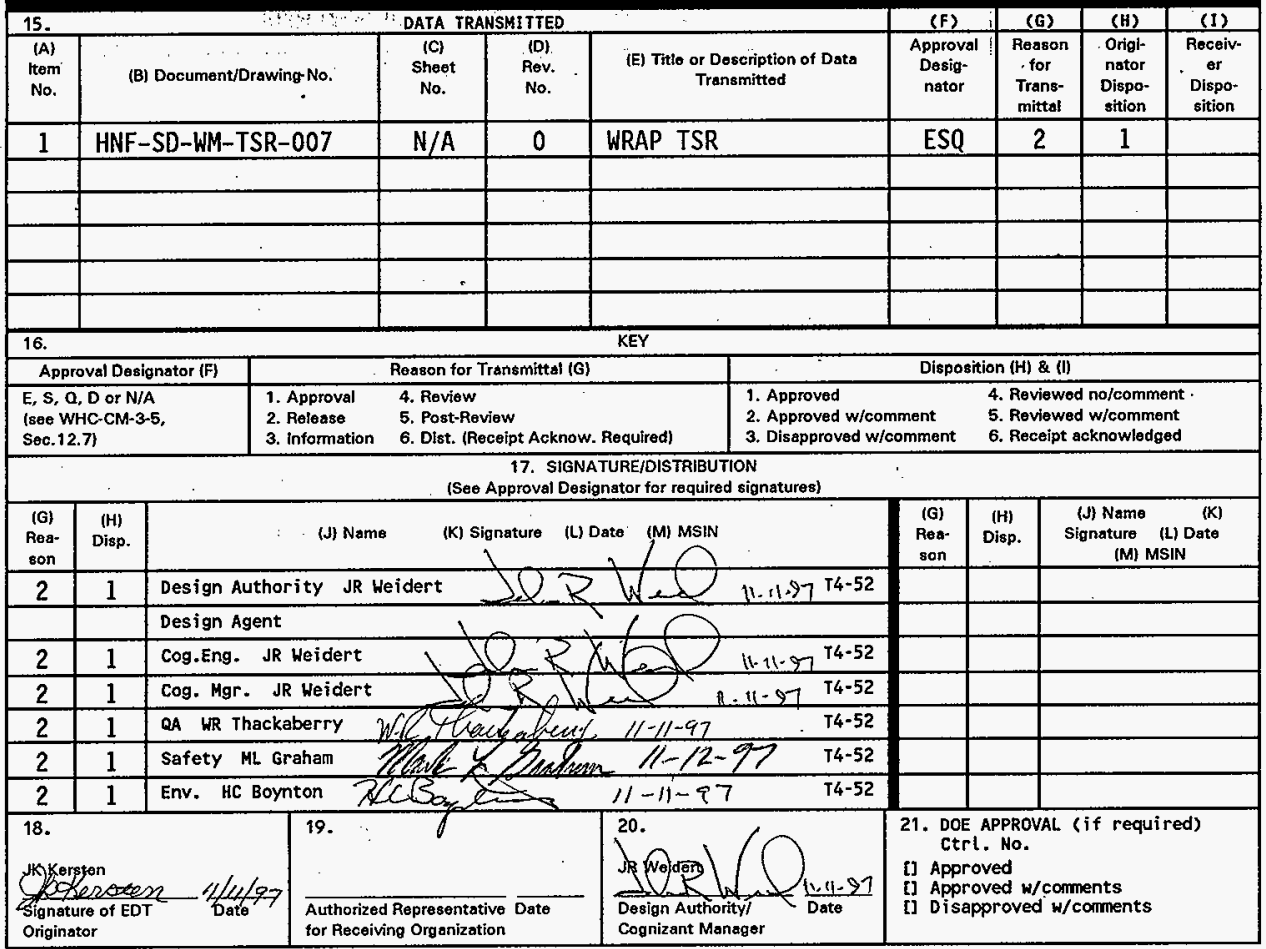




\title{
TECHNICAL SAFETY REQUIREMENTS (TSR) FOR WASTE RECEIVING AND PROCESSING FACILITY (WRAP) FACILITY
}

\author{
JR Weidert \\ Waste Management Federal Services of Hanford, Richland, WA 99352 \\ U.S. Department of Energy Contract DE-AC06-96RL13200
}

$\begin{array}{lll}\text { EDT/ECN: } & \text { EDT-620623 } & \text { UC: } 506 \\ \text { Org Code: } & 32620 & \text { Charge Code: } \\ \text { B\&R Code: } & \text { EW3130020 } & \text { Total Pages: } 41\end{array}$

Key Words: W-026, Safety, Limits, Basis, Administrative Controls

Abstract: The scope of this TSR document is based on the WRAP Final Safety Analys is Report (HNF-SD-W026-SAR-002) and supporting documents. The administrative controls set forth in this TSR document are derived from the WRAP Final Safety Analysis Report.

TRADEMARK DISCLAIMER. Reference herein to any specific comercial product, process, or service by trade name, trademark, manufacturer, or otherwise, does not necessarily constitute or imply its endorsement, recommendation, or favoring by the United States Government or any agency thereof or its contractors or subcontractors.

Printed in the United States of America. To obtain copies of this document, contact: Document Control Services, P.0. Box 950, Mailstop H6-08, Richland WA 99352, Phone (509) 372-2420;

Fax (509) 376-4989.
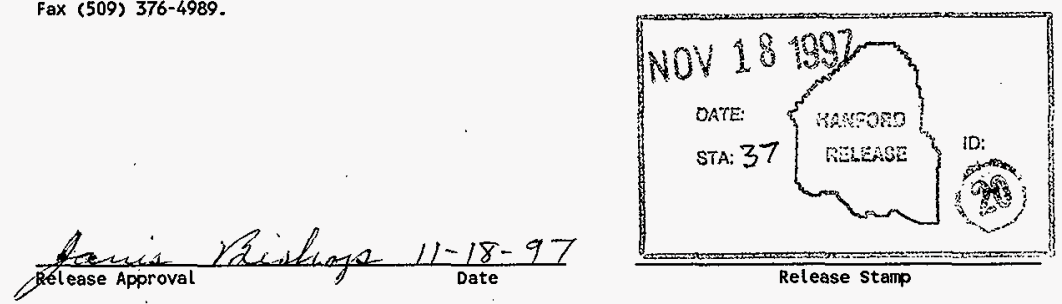


\section{WASTE RECEIVING AND PROCESSING FACILITY TECHNICAL SAFETY REQUIREMENTS \\ (200 West Area, Hanford Site) Revision 0}

HNF-SD-HM-TSR-007

Waste Management Federai Services of Hanford, Inc.

Richland, Washington

November 1997 
HNF-SD-WM-TSR-007 REV 0

This page intentionally left blank. 


\section{PREFACE}

These Technical Safety Requirements (TSRs) define the Administrative Controls required to ensure safe operation of the Waste Receiving and Processing Facility (WRAP). (As will be shown, Safety Limits, Limiting Control Settings, Limiting Conditions for Operation, and Surveillance Requirements are not required for safe operation of WRAP.)

The documentation format and content are based on U.S. Department of Energy Order 5480.22.

The scope of this TSR document is based on the WRAP Final Safety Analysis Report (HNF-SD-W026-SAR-002) and supporting documents. The administrative controls set forth in this TSR document are derived from the WRAP Final Safety Analysis Report. The WRAP operating contractor is responsible for establishing, implementing, and maintaining specific programs and procedures that meet the requirements of this TSR document.

The numbering and wording of the TSR sections are consistent with DOE Order 5480.22. The sections that do not apply to WRAP are noted. 
HNF-SD-WM-TSR-007 REV 0

This page intentionally left blank. 
1.0 USE AND APPLICATION ..................... 1- . . .

1.1 DEFINITIONS ..................... . . . . . . . . . . . .

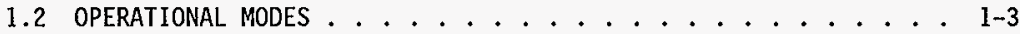

1.3 FREQUENCY . . . . . . . . . . . . . . 1-3

1.4 SAFETY LIMITS . . . . . . . . . . . . . . . . . . 1-3

1.5 LIMITING CONTROL SETTINGS . . . . . . . . . . . . . 1-4

1.6 LIMITING CONDITIONS FOR OPERATION . . . . . . . . . . 1-4

1.7 SURVEILLANCE REQUIREMENTS . . . . . . . . . . . . . . 1-4

1.8 ADMINISTRATIVE CONTROLS . . . . . . . . . . . . . . . 1-4

2.0 SAFETY LIMITS . . . . . . . . . . . . . 2-1

3.0 OPERATIONAL LIMITS . . . . . . . . . . . . . . . . . . . . . . . 3-1

3.1 LIMITING CONTROL SETTINGS . . . . . . . . . . . 3-2

3.2 LIMITING CONDITIONS FOR OPERATION .......... 3-2

4.0 SURVEILLANCE REQUIREMENTS ..................... 4-1

5.0 ADMINISTRATIVE CONTROLS ............... . . 5-1

5.1 TECHNICAL SAFETY REQUIREMENT VIOLATIONS . . . . . . . . 5-2

5.1.1 Violation Criteria . . . . . . . . . . . . 5-2

5.1.2 Response to a Safety Limit Violation [Not Applicable
to WRAP] . . 5-2

5.1.3 Response to a Limiting Control Setting or Limiting Conditions for Operation Violation [Not Applicable to WRAP] . . . . . . . 5-2

5.1.4 Response to a Surveillance Requirement Violation [Not Applicable to WRAP] . . . . . . . . 5-3

5.1.5 Response to an Administrative Control.Violation . . . 5-3

5.2 ORGANIZATION ..................... 5-3

5.2.1 Contractor Responsibility ......... 5-3

5.2.2 Organization and Management . . . . . . . . . 5-4

5.2.3 Staffing Requirements for Facility Positions

Important to Safe Operation of the Facility . . . . 5-4

5.2 .4 Audit Point ............... 5-6

5.3 NUCLEAR CRITICALITY SAFETY . . . . . . . . 5-6

5.3.1 Requirement for Nuclear Criticality Safety. . . . . . . 5-6

5.3.2 Program Key Elements . . . . . . . . . . . 5-6

5.3.3 Applicability ................ . 5-6

5.3 .4 Audit Point . . . . . . . . . . . . 5-6

5.4 INVENTORY CONTROL . . . . . . . . . . . . . . 5-7

5.4.1 Requirement for Inventory Control . . . . . . . 5-7

5.4 .2 Drum Limits for WRAP .............. . . 5-7

5.4.3 TRU Drum Limits for Process Enclosures . . . . . . . 5-7

5.4 .4 Wooden Box Limits .............. 5-8

5.4.5 Standard Waste Box Limits . . . . . . . . . . 5-8

5.4.6 Nonradiological Hazardous Inventory Control . . . . 5-8

5.4 .7 Applicability ................. 5-8

5.4 .8 Audit Point . . . . . . . . . . . . 5-8 


\section{CONTENTS (cont)}

5.5 COMBUSTIBLE LOADING . . . . . . . . . . . . . . . . . 5-9

5.5.1 Combustible Loads . . . . . . . . . . . . . . . . 5-9

5.5 .2 Audit Point . . . . . . . . . . . . 5-9

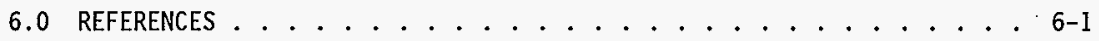

\section{APPENDICES}

A Bases .......................... A

B Design Features ........................... B- 


\begin{tabular}{ll} 
AS/RS & automated stacker/retrieval system \\
CPS & criticality prevention specification \\
DE-Ci & dose equivalent-curie \\
DOE & U.S. Department of Energy \\
FGE & fissile gram equivalent \\
FSAR & Final Safety Analysis Report \\
NDA & nondestructive assay \\
NDE & nondestructive examination \\
PHMC & Project Hanford Management Contractor \\
PSO & Program Secretarial Officer \\
SSC & structures, systems, and components \\
TRU & transuranic \\
TSR & technical safety requirement \\
WMH & Waste Management Federal Services of Hanford, Inc. \\
WRAP & Waste Receiving and Processing Facility \\
\hline \hline
\end{tabular}


HNF-SD-WM-TSR-007 REV 0

This page intentionally left blank. 


\subsection{USE AND APPLICATION}

This section contains basic information and instructions for using and applying the WRAP TSRs. 


\subsection{DEFINITIONS}

The following terms have unique definitions and appear in CAPITAL LETTERS and apply throughout this TSR document. Some terms refer the user to another section for the definition. The reason for this is to prevent a shortened definition from being supplied and used out of context.

$\underline{T e r m}$

BASES

MODE/OPERATIONAL MODES

OPERABLE/OPERABILITY

VERIFY/VERIFIED/

VERIFICATION

VIOLATION

\section{Definition}

BASES are pertinent information and details supporting TSR elements and specific values or characteristics. Appendix A contains TSR BASES.

OPERATIONAL MODES establish operating conditions at WRAP. OPERATIONAL MODES are defined in Section 1.2 .

A system, subsystem, train, component, or device shall be OPERABLE or have OPERABILITY when it is capable of performing its specified safety function(s), and: (a) actuation points are within limits, (b) operating parameters are within 1 imits, and (c) al1 necessary attendant equipment, instrumentation, controls, electrical power sources, cooling water, lubrication or other auxiliary equipment required for the system, subsystem, train, component, or device to perform its specified function(s) are capable of performing their related support functions.

A qualitative assessment to confirm or substantiate that specific conditions are met, and, if not, to ensure that a response is taken to satisfy the requirements. This could include collecting sample data or quantitative data; taking instrument readings; adjusting instrumentation set points; recording data and information on logs, data sheets or electronic media; and evaluating data and information according to approved and controlled procedures.

Refer to Section 5.1, TSR VIOLATIONS 


\subsection{OPERATIONAL MODES}

The OPERATIONAL MODES defined for WRAP are as follows.

OPERATION The mission of the facility or its current campaign is being performed.

SHUTDOWN The facility is not performing its mission or its current campaign, and is incapable of doing so in its present condition.

WARM STANDBY The facility is not operating but still retains its inventory of hazardous material.

COLD STANDBY The facility is not operating with its hazardous material inventory removed.

REPAIR The facility is not able to perform its mission in its current condition.

RESTRICTED Restricted area(s) or activity is defined. Receipt of additional waste containers in the area(s) affected by the restriction is not allowed. Processing of waste containers is not allowed in the area(s) affected by the restriction unless specifically authorized by an approved recovery plan. Routine inspections and maintenance could occur.

\subsection{FREQUENCY}

This section does not apply to WRAP because there are no frequency requirements specified in these TSRs.

\subsection{SAFETY LIMITS}

SAFETY LIMITS are limits on process variables associated with those physical barriers, generally passive, that are necessary for the intended facility to function and that are required to guard against the uncontrolled release of radioactivity and other hazardous materials that would result in unacceptable dose consequences as described in the WRAP Final Safety Analysis Report (FSAR) (HNF-SD-W026-SAR-002). As shown by the safety analysis performed and documented in HNF-SD-W026-SAR-002, no safety 1 imits are required.

[There are no SAFETY LIMITS identified for WRAP, based on the WRAP FSAR (HNF-SD-W026-SAR-002).] 


\subsection{LIMITING CONTROL SETTINGS}

LIMITING CONTROL SETTINGS are settings on safety systems that control process variables to prevent exceeding SAFETY LIMITS.

[There are no LIMITING CONTROL SETTINGS identified for WRAP because there are no SAFETY LIMITS, as described in Section 1.4.]

\subsection{LIMITING CONDITIONS FOR OPERATION}

LIMITING CONDITIONS FOR OPERATION are the lowest functional capability or performance level of safety-related structures, systems, and components (SSCs) and the support systems that are required for normal safe operation.

LIMITING CONDITIONS FOR OPERATION are based on maintaining the systems and structures OPERABLE or conditions within specified $1 \mathrm{imits}$ that are required for the protection of the offsite public from unacceptable consequences, as defined by the FSAR (HNF-SD-W026-SAR-002).

[There are no LIMITING CONDITIONS FOR OPERATION identified for WRAP, based on the WRAP FSAR (HNF-SD-W026-SAR-002).]

\subsection{SURVEILLANCE REQUIREMENTS}

SURVEILLANCE REQUIREMENTS are requirements relating to testing, calibration, or inspection to ensure that the necessary OPERABILITY and quality of safety-related SSCs and the support systems that are required for safe operation are maintained. SURVEILLANCE REQUIREMENTS are those requirements needed to maintain operation with in the SAFETY LIMITS, LIMITING CONTROL SETTINGS, and LIMITING CONDITIONS FOR OPERATIONS.

[There are no SURVEILLANCE REQUIREMENTS identified for WRAP because there are no SAFETY LIMITS, LIMITING CONTROL SETTINGS, Or LIMITING CONDITIONS FOR OPERATIONS identified in the WRAP FSAR (HNF-SD-W026-SAR-002).]

\subsection{ADMINISTRATIVE CONTROLS}

ADMINISTRATIVE CONTROLS are the provisions relating to organization and management, procedures, recordkeeping, reviews, and audits necessary to ensure safe operation.

ADMINISTRATIVE CONTROLS must include [per paragraph $9(\mathrm{e})(5)$ of U.S. Department of Energy (DOE) Order 5480.22] controls for reporting deviations from TSRs, staffing requirements for positions important to safe operation, and physical and administrative controls of the criticality safety program.

In addition, page 73 of DOE-STD-3009-94 requires that TSR ADMINISTRATIVE CONTROLS contain commitments to establish, maintain, and implement safety management programs. 
Chapter 5.0 of the FSAR (HNF-SD-W026-SAR-002) provides the derivation of the TSR ADMINISTRATIVE CONTROLS, which include those for contractor responsibility, organization and management, inventory control, and combustible loading.

WRAP TSR ADMINISTRATIVE CONTROLS are located in Section 5.0 of this. TSR Document. 
This page intentionally left blank. 
2.0 SAFETY LIMITS 
There are no SAFETY LIMITS identified for WRAP, as discussed in Section 1.4 of this TSR document. 
3.0 OPERATIONAL LIMITS 


\subsection{LIMITING CONTROL SETTINGS}

There are no LIMITING CONTROL SETTINGS identified for WRAP, as discussed in Section 1.5 of this TSR document.

\subsection{LIMITING CONDITIONS FOR OPERATION}

There are no LIMITING CONDITIONS FOR OPERATION identified for WRAP, as discussed in Section 1.6 of this TSR document. 


\subsection{SURVEILLANCE REQUIREMENTS}


There are no SURVEILLANCE REQUIREMENTS identified for WRAP, as discussed in Section 1.7 of this TSR document. 


\subsection{ADMINISTRATIVE CONTROLS}


HNF-SD-WM-TSR-007 REV 0

\subsection{TECHNICAL SAFETY REQUIREMENT VIOLATIONS}

\subsubsection{Violation Criteria}

VIOLATIONS of TSRs occur as the result of the following four circumstances:

a. Exceeding a SAFETY LIMIT [Not Applicable to WRAP].

b. Failure to take the ACTIONS required within the required time limit following:

1. Exceeding a LIMITING CONTROL SETTING [Not Applicable to WRAP].

2. Failure to meet a LIMITING CONDITION FOR OPERATION [Not Applicable to WRAP].

3. Failure to successfully meet a SURVEILLANCE REQUIREMENT [Not Applicable to WRAP].

c. Failure to perform a Surveillance within the required time Timit [Not Applicable to WRAP].

d. Failure to comply with an ADMINISTRATIVE CONTROL requirement.

An ADMINISTRATIVE CONTROL VIOLATION occurs: (a) when a required program has not been established; (b) when the program has been established but the facility has not implemented the program; or (c) when the failure to comply with the program requirements specified for Contractor Responsibilities, Minimum Operations Shift Complement, Requirements for Nuclear Criticality Safety, Combustible Loadings, and/or Inventory Control results in WRAP operations exceeding the analyzed authorization basis.

If during implementation of the required program a procedural element is discovered not to have been performed or not to have been followed, then a procedural noncompliance would result, but not necessarily an ADMINISTRATIVE CONTROL VIOLATION unless the noncompliance results in WRAP operations exceeding the analyzed authorization basis.

\subsubsection{Response to a Safety Limit Violation [Not Applicable to WRAP]}

\subsubsection{Response to a Limiting Control Setting or Limiting Conditions} for Operation Violation [Not Applicable to WRAP] 


\subsubsection{Response to a Surveillance Requirement Violation [Not Applicable to WRAP]}

\subsubsection{Response to an Administrative Control Violation}

If a VIOLATION of an ADMINISTRATIVE CONTROL occurs, proceed as follows:

a. P1ace WRAP or the affected area(s) (or activity) of WRAP in RESTRICTED MODE and notify the DOE of the VIOLATION according to DOE occurrence reporting requirements.

b. Prepare an 0ccurrence Report according to DOE occurrence reporting requirements.

c. Prepare and implement a Recovery Plan describing the steps leading to compliance with the Administrative Control.

d. Perform and document a technical evaluation, if appropriate, of the ADMINISTRATIVE CONTROL violation to determine if any damage occurred.

e. Perform and document a root cause analysis and implement a corrective action $\mathrm{plan}$, if appropriate, to minimize the chance of recurrence.

\subsection{ORGANIZATION}

\subsubsection{Contractor Responsibility}

The Operating Contractor, Waste Management Federal Services of Hanford, Inc. (WMH), shall be responsible to the Project Hanford Management Contractor (PHMC) for the safe operation of WRAP in accordance with this TSR document as approved by the DOE Program Secretarial officer (PSO), or designee, including any modifications made by the designated DOE approval authority.

WMH shall be responsible for operating WRAP within the approved safety basis and for maintaining the current DOE-approved FSAR and TSRs as controlled documents. Programs developed to assure safe and healthful operation of nuclear facilities on the Hanford Site are implemented at WRAP as discussed in Chapter 17.0 of the FSAR (HNF-SD-W026-SAR-002). Most of these are mentioned or discussed in Chapters 6.0 through 17 of the FSAR (HNF-SD-W026-SAR-002).

The following institutional safety programs are implemented and maintained by WRAP personnel. Additional programs provide significant contributions to a successfut facility operation; however, these programs are not specifically identified and dictated by the facility authorization basis.

- Unreviewed safety question

- Operations (HNF-SD-W026-SAR-002, Chapter 11.0) 
- Radiation protection (HNF-SD-W026-SAR-002, Chapter 7.0)

- Quality assurance (HNF-SD-W026-SAR-002, Chapter 14.0)

- Fire protection (HNF-SD-W026-SAR-002, Chapter 11.0)

- Environmental protection

- Nuclear criticality safety (HNF-SD-W026-SAR-002, Chapter 6.0)

- Nuclear safety

- Industrial safety

- Industrial hygiene

- Emergency management (HNF-SD-W026-SAR-002, Chapter 15.0)

- Standard engineering practices

- Project management

- Training

- ALARA (HNF-SD-W026-SAR-002, Chapter 7.0).

WMH sha1l establish the WRAP MODE status to assure the facility status is documented and remains current.

WMH may take emergency actions that depart from the approved TSRs when no actions that are consistent with the TSR are immediately apparent, and when these actions are needed to protect the public health and safety. Such contractor actions shall be approved, as a minimum, by the lead operator or supervisor. If emergency actions are taken that are not covered by existing emergency procedures, verbal notifications shall be made in accordance with DOE occurrence reporting requirements.

\subsubsection{Organization and Management}

Lines of authority, responsibility, and communication shall be established and defined for al1 WRAP management levels, to the highest responsible authority. These relationships shall be documented and updated, as appropriate, in the form of organization charts, functional descriptions of departmental responsibilities and relationships, or in equivalent forms of documentation. Organization charts and/or charters describing the organization, lines of authority, and responsibilities shall be issued whenever the charts or functions change or annually, whichever occurs first. Discussion of organizational structure and organization charts are provided in Chapter 17.0 of the FSAR (HNF-SD-W026-SAR-002).

The WRAP Plant Manager shall be responsible for the safe operation of WRAP. Safe operation shall include, as necessary, interface requirements with other onsite organizations and facilities.

The PHMC Environmental Safety and Health organization shall provide for independent safety overview and quality assurance functions to ensure safe operation of WRAP.

\subsubsection{Staffing Requirements for Facility Positions Important to Safe Operation of the Facility}

The number of qualified shift managers and operators available shall be adequate to safely operate and support WRAP activities. The minimum operations shift complement, for surveillance and many other routine 
activities during operation mode, shall be based on the shift manager, or designee, being available. Management shall provide additional personnel, as necessary, to safely perform all required functions in accordance with written procedures. The bases for minimum shift complements and normal operating complements are discussed in the FSAR, Chapter 2.0 and 17.0

(HNF-SD-W026-SAR-002). Also addressed in Chapter 17.0 (HNF-SD-W026-SAR-002) are restrictions on extended working hours.

The minimum operations complement per WRAP shift shall be as follows:

\begin{tabular}{|c|c|c|}
\hline MODE & Supervision ${ }^{1}$ & Operators \\
\hline \multicolumn{3}{|l|}{ OPERATION } \\
\hline Surveit1 ance & 1 & 1 (operator or RCT) \\
\hline Receive/ship drums & 1 & $\begin{array}{l}1 \text { operator } \\
1 \text { RCT }\end{array}$ \\
\hline X-ray drums & 1 & $\begin{array}{l}1 \text { operator } \\
1 \text { NDE technician }\end{array}$ \\
\hline Assay drums & 1 & 1 operator \\
\hline Assay and X-ray drums & 1 & $\begin{array}{l}1 \text { operator } \\
1 \text { NDE technician }\end{array}$ \\
\hline $\begin{array}{l}\text { Glovebox operation } \\
\text { LLW/TRU }\end{array}$ & 1 & $\begin{array}{ll}1 & \text { operator } \\
1 & \mathrm{RCT}\end{array}$ \\
\hline $\begin{array}{l}\text { Glovebox operation } \\
\text { LLW and TRU }\end{array}$ & 1 & $\begin{array}{l}2 \text { operators } \\
1 \text { RCT }\end{array}$ \\
\hline $\begin{array}{l}\text { Glovebox operation } \\
\text { LLW, TRU and RWM (LLW) }\end{array}$ & 1 & $\begin{array}{l}3 \text { operators } \\
1 \text { RCT }\end{array}$ \\
\hline $\begin{array}{l}\text { Glovebox operation } \\
\text { LLW, TRU and RWM } \\
\text { (LLW and TRU) }\end{array}$ & 1 & $\begin{array}{l}4 \text { operators } \\
1 \text { RCT }\end{array}$ \\
\hline X-ray boxes & 1 & $\begin{array}{l}1 \text { operator } \\
1 \text { NDE technician }\end{array}$ \\
\hline Assay boxes & 1 & 1 operator \\
\hline SHUTDOWN & 0 & 0 \\
\hline WARM STANDBY & 0 & 0 \\
\hline COLD STANDBY & 0 & 0 \\
\hline REPAIR & As required & As required \\
\hline RESTRICTED & As required ${ }^{2}$ & As required ${ }^{2}$ \\
\hline
\end{tabular}

${ }^{1}$ Supervisor or lead operator. The lead operator can also fulfill the requirement of an operations operator but cannot concurrently fulfill the requirements of both positions.

2 Staffing requirements shall be defined in the specific Recovery Plan prepared when WRAP has been placed in Restricted MODE.

$L L W=10 \mathrm{~W}$ - Tevel waste; $\mathrm{NDE}=$ nondestructive examination;

$\mathrm{RCT}$ = radiological control technician; $\mathrm{RWM}$ = restricted waste management; TRU = transuranic 


\subsubsection{Audit Point}

WRAP management will issue organization charts and/or charters describing the organization, lines of authority, and responsibilities; at least annually, as required by Section 5.2.2.

\subsection{NUCLEAR CRITICALITY SAFETY}

\subsubsection{Requirement for Nuclear Criticality Safety}

A program shall be established, implemented, and maintained so that an accidental criticality at WRAP remains an incredible event. The fissile material reactivity shall have a k-effective plus two standard deviations of 0.95 or less.

\subsubsection{Program Key Elements}

a. The nuclear criticality safety program maintains a fissile materials inventory compliant with the classifications as a Limited Control Facility for the Shipping/Receiving (WHC-SD-SQA-CSA-516) and NDE/NDA areas and up to three Isolated Facilities for the Process Area (WHC-SD-SQA-CSA-510). The current criticality prevention specification (CPS) covering the operations in the Shipping/receiving and NDE/NDA areas of WRAP is WRP1-CPS-001. Assurance against a criticality incident in the process enclosures shall be based on the criticality safety analysis documented in WHC-SD-SQA-CSA-510.

b. In the event the CPS (WRP1-CPS-001) or CSA (WHC-SD-SQA-CSA-510) requirements are not met, notification will be immediate and will include the WRAP manager and the manager of Criticality and Radiological Analysis. The cause of the deficiency will be determined and a course of action to correct the problem will be implemented. (A11 requirements appiy for actions to be taken if a TSR violation occurs.)

c. The information and reports for determining fissile amounts of containers/material, together with container placement records, will be retained that demonstrate the CPS requirements are being met.

\subsubsection{Applicability}

This program applies to all areas within WRAP.

\subsubsection{Audit Point}

An annual review of WRAP criticality safety program will be conducted by the facility's criticatity safety representative. This annual review will 
evaluate results of the quarterly criticality safety inspections and verify the requirements outlined in Section 5.3.1 are being met. The result of this annual review will be documented and retained by the facility's criticality safety representative and forwarded to DOE for information.

\subsection{INVENTORY CONTROL}

\subsubsection{Requirement for Inventory Control}

A program shall be established, implemented, and maintained such that WRAP will operate within the approved safety basis and the inventories assumed and documented in Chapter 3.0 of the FSAR (HNF-SD-W026-SAR-002), shall not be exceeded. The dose equivalent-curie $(D E-C i)$ value of a container is derived by multiplying the number of curies of each isotope by the isotope's dose conversion factor ratio, and summing the results for a11 isotopes. This sum cannot exceed 35.0 DE-Ci per drum, 35.0 DE-Ci per wooden box or $56.9 \mathrm{DE}-\mathrm{Ci}$ per standard waste box. The bounding facility inventory of $1,433 \mathrm{DE}-\mathrm{C} i$ shall not be exceeded. The program shall include operation, calibration, and testing of nondestructive assay (NDA) equipment. Elements of the inventory control program shall include the following:

- Drum limits for WRAP

- TRU drum limits for process enclosures

- Wooden box limits

- Standard waste box limits

- Nonradiological hazardous inventory control.

\subsubsection{Drum Limits for WRAP}

A 35.0 DE-Ci per-drum 1 imit will not be exceeded for drums entering WRAP. If radiological content of drummed waste is discovered to be higher than the 35.0 DE-Ci per-drum limit, appropriate recovery actions wiTl be implemented to maintain the established limit. To maintain FSAR compliance, the initial recovery action will be completed within 4 hours. If the initial recovery action is to remove the drum from the facility or place the drum into a Type $B$ overpack, an analysis must be completed before the container can be returned to WRAP or removed from the Type B container.

\subsubsection{Fissile Limits for Process Enclosures}

A p7utonium-239 FGE 1 imit of 177 grams shall not be exceeded for fissile material accumulated in WRAP process enclosures. If the plutonium-239 FGE limit of 177 grams for fissile material accumulated in WRAP process enclosures is exceeded, a violation of the requirements of Section 5.3.2 has occurred and the actions required by Section 5.1 .5 must be performed. 


\subsubsection{Wooden Box Limits}

A 35.0 DE-Ci limit will not be exceeded for wooden boxes entering WRAP. If radiological contents of wooden boxes are discovered to be higher than the 35.0 DE-Ci limit, appropriate recovery actions will be implemented to maintain the established limit. To maintain FSAR compliance, the initial recovery action will be completed within 4 hours. If the recovery action is to remove the box from the facility, an analysis must be completed before the box can be returned to WRAP.

\subsubsection{Standard Waste Box Limits}

A 1 imit of $56.9 \mathrm{DE}-\mathrm{Ci}$ will not be exceeded for SWBs in WRAP. If radiological contents of boxed waste are discovered to be higher than the $56.9 \mathrm{DE}-\mathrm{C} i$ limit, appropriate recovery actions will be implemented to maintain the established limit. To maintain FSAR compliance, the initial recovery action will be completed within 4 hours. If the initial recovery action is to remove the box from the facility, an analysis must be completed before the box can be returned to WRAP.

\subsubsection{Nonradiological Hazardous Inventory Control}

Acceptance of nonradiological hazardous waste materials at WRAP will be controlled in accordance with the methodology described in Chapter 3.0 , Section 3.4.2.6.3, of the FSAR (HNF-SD-W026-SAR-002) that ensures accidental exposures to facility workers, collocated workers, and the public will not exceed established guidelines. If nonradiological contents of a waste container are discovered to be higher than the analyzed 1 imit, appropriate recovery actions will be implemented to maintain the established limit. To maintain FSAR compliance, the initial recovery action will be completed within 4 hours. If the initial recovery action is to remove the container from the facility, an analysis must be completed before the container can be returned to WRAP.

\subsubsection{Applicability}

This program applies to all areas within WRAP.

\subsubsection{Audit Point}

Records are maintained that document inventories present in WRAP are consistent with Sections 5.4.1 through 5.4.6. These records are retained for a minimum of 2 years. 


\subsection{COMBUSTIBLE LOADING}

\subsubsection{Combustible Loads}

A program shall be implemented to control building combustibles so as to remain within the inventory analyzed in Chapter 3.0 and enumerated in Chapter 11.0, Section 11.4.3 of the FSAR (HNF-SD-W026-SAR-002).

\subsubsection{Audit Point}

A periodic surveillance shall be used to verify that actual WRAP combustible loads are maintained at less than the FSAR analyzed Timits. 
This page intentionally left blank. 


\subsection{REFERENCES}


Section 6.0: REFERENCES

DOE Order 5480.21, Unreviewed Safety Questions.

DOE Order 5480.22, Technical Safety Requirements, U.S. Department of Energy, Washington, D.C., 1992.

DOE-STD-3009-94, Preparation Guide for U.S. Department of Energy Nonreactor Facility Safety Analysis Reports, U.S. Department of Energy, Washington, D.C., 1994.

HNF-SD-W026-FHA-001, Rev. 0, Fire Hazard Analysis for Waste Receiving and Processing Facility, Hughes Associates, Inc., Baltimore, Maryland, 1997.

HNF-SD-W026-SAR-002, Waste Receiving and Processing Module 1 Facility Final Safety Analysis Report, Rev. 0, Rust Federal Services of Hanford Inc, Richland, Washington, June 1997.

WHC-SD-SQA-CSA-510, CSER 96-011; Designation of the WRAP 1 Facility as Up to Three Isolated Facilities, Rev. 0, Westinghouse Hanford Company, Richland, Washington, 1996.

WHC-SD-SQA-CSA-516, CSER 96-018; Designation of the Waste, Receipt, Storage, Assay and Shipping Portions of the WRAP 1 Facility as a Limited Control Facility," Rev. 0, Westinghouse Hanford Company, Richland, Washington, 1996. 
HNF-SD-WM-TSR-007 REV 0

Appendix A

BASES

Appendix A: BASES

A- $\mathbf{i}$ 
This page intentionally left blank. 
According to DOE Order 5480.22 , a BASES appendix is required to summarize the reasons for establishing SAFETY LIMITS, OPERATING LIMITS (LIMITING CONTROL SETTINGS AND LIMITING CONDITIONS FOR OPERATION), and associated SURVEILLANCE REQUIREMENTS. This appendix does not appTy to WRAP because there are no SAFETY LIMITS, LIMITING CONTROL SETTINGS, LIMITING CONDITIONS FOR OPERATION, or associated SURVEILLANCE REQUIREMENTS. BASES for the ADMINISTRATIVE CONTROLS of these TSRs are derived from the FSAR, Chapter 5.0 (HNF-SD-W026-SAR-002). 
This page intentionally left blank. 
Appendix B: DESIGN FEATURES 
This page intentionally left blank. 
DESIGN FEATURES are those features not covered el sewhere in the TSRs and that, if altered or modified, would have a significant effect on safety. Normally DESIGN FEATURES are built-in features that require infrequent maintenance or surveillance and normally are not subject to change by operations personnel. The categories of DESIGN FEATURES to be addressed in accordance with DOE 5480.22, Technical Safety Requirements, inciude the following:

a. Vital passive components such as piping, vessels, supports, confinement structures, and containers.

b. Configuration and physical arrangement of the facility where safety is a concern, including site characteristics such as the locations of public access roads, co-located facilities, facility area boundaries, site boundaries, and distances to the nearest residences.

c. Building materials, if the safe operation depends on any component being constructed of a particular material.

Changes to DESIGN FEATURES are considered significant modifications. The unreviewed safety question (USQ) process required by DOE 5480.21, Unreviewed Safety Questions, ensures that changes to DESIGN FEATURES are analyzed appropriately and controlled so that the changes do not adversely affect safe operation of WRAP. The DESIGN FEATURES for WRAP that would have a significant effect on safe operation if altered or modified are 1 isted below by functional area.

\section{Shipping and Receiving Area}

DESIGN FEATURES for the shipping and receiving area include the following:

- The AS/RS maintains structural integrity during a seismic event to prevent drums from falling and rupturing. The AS/RS maintains the drum array and stacking integrity.

- A concrete shield wall around the AS/RS/TRUPACT payload storage unit provides radiation shielding for personnel protection.

NDE/NDA Area

DESIGN FEATURES for the NDE/NDA area include the following:

- Shielding installed in all examination stations.

Waste Drum Processing Area

DESIGN FEATURES for the waste drum processing area include the following: 
- Process enclosures provide the primary containment for opened drums in case of a fire or explosion within the process enclosures. The process enclosures (bottom, sides, top, and viewing windows) are designated as safety-significant SSCs.

- Concrete shield walls around the drum buffer storage area. 
DISTRIBUTION SHEET

\begin{tabular}{|c|c|c|c|c|c|}
\hline \multirow{2}{*}{$\begin{array}{l}\text { To } \\
\text { Distribution }\end{array}$} & \multirow{2}{*}{\multicolumn{3}{|c|}{$\begin{array}{l}\text { From } \\
\text { WRAP Engineering }\end{array}$}} & \multicolumn{2}{|l|}{ Page 1 of 1} \\
\hline & & & & \multicolumn{2}{|c|}{ Date $11 / 11 / 97$} \\
\hline \multirow{2}{*}{\multicolumn{4}{|c|}{$\begin{array}{l}\text { Project Title/Work Order } \\
\text { HNF-SD-WM-TSR-007, WRAP TECHNICAL SAFETY REQUIREMENTS (TSR) }\end{array}$}} & \multicolumn{2}{|c|}{ EDT No. 620623} \\
\hline & & & & \multicolumn{2}{|c|}{ ECN No. N/A } \\
\hline Name & MSIN & $\begin{array}{l}\text { Text } \\
\text { With All } \\
\text { Attach. }\end{array}$ & Text Only & $\begin{array}{l}\text { Attach./ } \\
\text { Appendix } \\
\text { Only }\end{array}$ & $\begin{array}{c}\text { EDT/ECN } \\
\text { Only }\end{array}$ \\
\hline
\end{tabular}

RJ Bottenus

T4-51 X

HC Boynton

T4-52

$X$

LD Early

S7-41 $\quad X$

MS French

S7-55

$x$

ML. Graham

T4-52

$X$

JK Kersten

(2 copies)

T4-52

$X$

SL Kooiker

T4-51

X

LW Roberts

T4-51 X

KJ Svoboda

N1-26 $X$

RB Swallow

T4-51

X

JD Voice

A5-55

X

WR Thackaberry

T4-52

$X$

JR Weidert

(2 copies)

T4-52

X

Central Files

BI-07 $X$

$D P C$

A3-94 $X$

EOMC

WMFSH FiTe (2 copies)

H6-08 $X$

ᄂ4-97 $X$ 